\title{
Vitamin D Is Necessary for Murine Gastric Epithelial Homeostasis
}

\author{
Ifrah Ismail Ali ${ }^{1}$, Iltaf Shah ${ }^{2}\left(\mathbb{D}\right.$, Sayed Marzouk ${ }^{2}$, Sherif M. Karam ${ }^{3}{ }^{(1)}$ and Asma Al Menhali $1, * \mathbb{C}$ \\ 1 Department of Biology, College of Science, United Arab Emirates University, \\ Al Ain 15551, United Arab Emirates; 200540058@uaeu.ac.ae \\ 2 Department of Chemistry, College of Science, United Arab Emirates University, \\ Al Ain 15551, United Arab Emirates; altafshah@uaeu.ac.ae (I.S.); sayedm@uaeu.ac.ae (S.M.) \\ 3 Department of Anatomy, College of Medicine \& Health Sciences, United Arab Emirates University, \\ Al Ain 15551, United Arab Emirates; skaram@uaeu.ac.ae \\ * Correspondence: asmaa@uaeu.ac.ae; Tel.: +971-3-713-6380
}

check for updates

Citation: Ali, I.I.; Shah, I.; Marzouk, S.; Karam, S.M.; Al Menhali, A. Vitamin D Is Necessary for Murine Gastric Epithelial Homeostasis. Biology 2021, 10, 705. https://doi.org/10.3390/ biology10080705

Academic Editor: Riccardo Ientile

Received: 14 June 2021

Accepted: 20 July 2021

Published: 23 July 2021

Publisher's Note: MDPI stays neutral with regard to jurisdictional claims in published maps and institutional affiliations.

Copyright: (c) 2021 by the authors. Licensee MDPI, Basel, Switzerland. This article is an open access article distributed under the terms and conditions of the Creative Commons Attribution (CC BY) license (https:/ / creativecommons.org/licenses/by/ $4.0 /)$.
Simple Summary: The gastric epithelium comprises multiple cell types that undergo continuous renewal through controlled proliferation, differentiation and death. Several vitamins, such as vitamin $\mathrm{D}$ (VD), are known to contribute to tissue homeostasis and numerous studies have shown the importance of VD in different body organ systems. However, VD's normal function in the stomach is understudied. To better understand the role of VD in the murine stomach, we initially confirmed the expression of VD receptors (VDR) in the stomach. Mice were fed a VD-deficient diet for 3 months. The results showed that the proton pump of acid-secreting parietal cells was downregulated in vitamin D-deficient mice and contributed to an abnormal gastric physiology. Moreover, this diet increased the gastrin hormone gene expression and increased gastric epithelial cell proliferation. These findings suggest essential biological roles for VDR and VD in gastric epithelial homeostasis. Future research will be required to explore this phenomenon in humans.

Abstract: Unlike other organs, the importance of VD in a normal stomach is unknown. This study focuses on understanding the physiological role of vitamin D in gastric epithelial homeostasis. C57BL/6J mice were divided into three groups that were either fed a standard diet and kept in normal light/dark cycles (SDL), fed a standard diet but kept in the dark (SDD) or fed a vitamin D-deficient diet and kept in the dark (VDD). After 3 months, sera were collected to measure vitamin D levels by LC-MS/MS, gastric tissues were collected for immunohistochemical and gene expression analyses and gastric contents were collected to measure acid levels. The VDD group showed a significant decrease in the acid-secreting parietal cell-specific genes Atp $4 a$ and Atp $4 b$ when compared with the controls. This reduction was associated with an increased expression of an antral gastrin hormone. VDD gastric tissues also showed a high proliferation rate compared with SDL and SDD using an anti-BrdU antibody. This study indicates the requirement for normal vitamin D levels for proper parietal cell functions.

Keywords: vitamin $\mathrm{D}$ receptor; vitamin $\mathrm{D}_{3}$; gastric epithelial homeostasis; cell proliferation; cell differentiation

\section{Introduction}

Vitamins are nutritional factors required in small quantities that play important roles in human development, reproduction and tissue maintenance [1]. Although many vitamins are obtained through diet, several, such as vitamin D (VD) [1], are changed into their effective forms, which require further activation in the body. VD is universally known as a steroidal hormone because it has pro-steroids as a precursor. VD exists in two forms, $\mathrm{VD}_{2}$ (ergocalciferol) [2] and $\mathrm{VD}_{3}$ (cholecalciferol) [3]. Both $\mathrm{VD}_{2}$ and $\mathrm{VD}_{3}$ could be derived from food and dietary supplements; however, the primary source of cholecalciferol is the skin. 7-dehydrocholesterol, the precursor of $\mathrm{VD}_{3}$, is naturally found in epidermal cells. 
7-dehydrocholesterol is converted into $\mathrm{VD}_{3}$ in the plasma membrane following exposure to ultraviolet $\mathrm{B}$ radiation from the sun. $\mathrm{As}_{\mathrm{VD}} \mathrm{VD}_{3}$ reaches the extracellular fluid and then the blood, it is relocated to the liver after binding to a VD binding protein (DBP) [4]. Within the liver, the enzymes sterol 27-hydroxylase (CYP27A1) and 25-hydroxylase (CYP2R1) turn $\mathrm{VD}_{3}$ into 25 -hydroxyvitamin $\mathrm{D}_{3}\left(25 \mathrm{OHD}_{3}\right)$, which is then primarily translocated to the kidney via the DBP where it is hydroxylated further by $1 \alpha$-hydroxylase (CYP27B1) to become the biologically active form, $1 \alpha, 25$-dihydroxyvitamin $\mathrm{D}_{3}\left(1 \alpha, 25(\mathrm{OH})_{2} \mathrm{D}_{3}\right)$. This active form is transported to multiple target tissues, including bone and the intestines, to perform its biological functions [5].

The VD receptor (VDR) is a nuclear receptor [6] and it belongs to receptor subfamily 1 , group I and member 1 [7]. The function of the VD receptor is strongly dependent on its molecular nature and its particular structure. In most cases, when $1 \alpha, 25(\mathrm{OH})_{2} \mathrm{D}_{3}$ is attached, the VDR will act as a ligand-dependent transcription factor and it will also allow the $1 \alpha, 25(\mathrm{OH})_{2} \mathrm{D}_{3}$-VDR complex to interact with RXR. These $1 \alpha, 25(\mathrm{OH})_{2} \mathrm{D}_{3}$-VDR-RXR heterodimers are carried to the nucleus where they bind to VD response elements (VDRE) in the promoter sequence of the VD target genes. Thus, the activated VDR directly induces coactivators and corepressors that regulate the transcription of target genes and translation of target proteins responsible for mediating VDR functions [8,9]. Target genes include $\mathrm{Ca}^{2+}$ channels and transient receptor potential vanilloid member 6 (TRPV6) [10], important in inducing a capsaicin-dependent apoptosis in gastric cancer cells [11]. $1 \alpha, 25(\mathrm{OH})_{2} \mathrm{D}_{3}$ also regulates the transcription of the parathyroid hormone-like hormone (Pthlh) [12] and it is also involved in the activation of osteoclasts and the proliferation and differentiation of chondrocytes [13]. Moreover, via VDRE binding, $1,25(\mathrm{OH})_{2} \mathrm{D}_{3}$ also regulates the transcription of tumor suppressor p21, which causes cell cycle arrest and initiates apoptosis $[14,15]$.

Previous studies have identified VD target tissues throughout the gastrointestinal tract and in multiple animal species [16]. The injection of radio-labeled $1 \alpha, 25(\mathrm{OH})_{2} \mathrm{D}_{3}$ into mice, rats, hamsters and zebrafish has revealed many sites for ligand binding in the colon, stomach and small intestine [16]. Moreover, VDR expression has been identified in the gastrointestinal tracts of mice, rats and humans [17-19]. The roles of VD and VDR in the intestine have been well studied. Adequate calcium absorption in the intestine is maintained by VD targets such as intestinal plasma membrane calcium ATPase (PMCA) and TRPV6 [20].

At the cellular level, different immune cells involved in gastrointestinal immunity express the VDR and they are part of VD production, such as B and T lymphocytes, macrophages and dendritic cells [21]. Within the stomach, the scattered cells in the pyloric antrum and the isthmus region in the corpus were discovered as target tissues of $3 \mathrm{H}-$ $1 \alpha, 25(\mathrm{OH})_{2} \mathrm{D}_{3}$ [16]. The normal function of VD in the stomach is yet to be explored.

Interestingly, the VDR was found to be poorly expressed or downregulated in malignant gastric tissue [22] and tissues obtained from Barrett's esophagus [19]. It was found that the VDR was expressed at a higher level in moderately differentiated premalignant gastric tissues than in poorly differentiated premalignant gastric tissues $[19,22]$. In addition, it was reported that VD deficiency is associated with other gastrointestinal diseases such as inflammatory bowel disease, colorectal cancer and Helicobacter pylori infection [23-25]. Thus, it is fundamentally important to define the VDR expression patterns and function in normal gastric tissues to provide basic information for the understanding of the pathogenesis of gastric cancer.

The stomach in humans and rodents is structurally subdivided into four parts: the cardia body (or corpus), the fundus (or forestomach) and the pylorus, which includes the antrum and sphincter [26,27]. In rodents, the epithelial layer of the corpus, pylorus and cardia is organized to form tubular glands, which are populated with different epithelial cell types [28]. There are four unique regions in the corpus gastric gland: the pit, isthmus, neck and base. The isthmus region contains stem cells and their immediate descendants (progenitors) that give rise to the cells of the corpus gland upon differentiation. The luminal surface and the pit region contain mucous cells that secrete mucus. The neck region contains 
mucus-secreting neck cells. Parietal cells produce hydrochloric acid and enteroendocrine cells are dispersed all over the gland regions. The pepsinogen is secreted by the zymogenic (chief) cells, which are located only in the basal region [26,29]. The antral gastric gland is composed of surface mucous cells in the pit region and gland mucous cells in the basal region while the antral stem/progenitor cells in the isthmus/base and enteroendocrine cells are scattered throughout $[30,31]$. Stem cells not only maintain gastric epithelial homeostasis but also continuously proliferate and differentiate and form all kinds of specialized gastric epithelial cells [28,32]. Although previous studies reported correlations between cancer progression, $\mathrm{Ca}^{2+}$ activity and VDR signaling, the clear role of the VDR in the stomach, as well as its role in gastric homeostasis, remains obscure. Therefore, this study was planned to determine the normal expression, distribution and cellular expressions of the VDR in gastric epithelia and the effects of VD3 deficiency on gastric stem cell proliferation and their differentiated descendants. We used immunohistochemistry, real-time PCR and RT-PCR to test our hypothesis that the differentiation and proliferation of gastric epithelial cells are dependent on the VDR function.

\section{Materials and Methods}

\subsection{Mice and Their Diets}

The ethics committee of the United Arab Emirates University approved this study (UAEU, ERA_2017_5684). C57BL/6J mice were kept in autoclaved filter-top cages and handled in a laminar flow hood at the facility allocated for animal research at the College of Medicine and Health Sciences at UAEU.

Three-week-old weaned male mice $(n=30)$ were distributed into three equal groups based on light exposure and diet. The control group was kept on a standard rodent diet, AIN-93G, which included 1000 international units (IU) of VD $_{3}$ (D10012Gi, Research Diet, New Brunswick, NJ, USA) in a $12 \mathrm{~h}$ dark/light cycle (SDL). The second group was given the standard diet and maintained in the dark with no overhead light (SDD). The third group ( $\mathrm{VD}_{3}$-deficient; VDD) was maintained on a growing rodent diet, AIN-93G, with a $25 \mathrm{IU} \mathrm{VD} / \mathrm{kg}$ diet (D17053003i, Research Diet) with no light source provided. These conditions were kept for three months for all mice.

\subsection{Histology}

Gastric tissues were collected from the euthanized mice and fixed with Bouin's fixative for $24 \mathrm{~h}$. Ethanol was used to dehydrate the tissue, xylene was used to clear the tissue and paraffin was then used to embed the tissue. Hematoxylin and eosin (H\&E) or periodic acid-Schiff (PAS) were used to stain the tissue sections $(5 \mu \mathrm{m})$. Several tissue sections were processed for immunoperoxidase and immunofluorescent staining. The images were obtained using an Olympus microscope IX83 (Tokyo, Japan).

A PAS staining kit (Newcomer Supply, Middleton, WI, USA) was used to prepare the samples for imaging. The slides were incubated with periodic acid $(0.5 \%)$ for $10 \mathrm{~min}$ and then with the Schiff reagent for $20 \mathrm{~min}$. The tissues were counterstained with the hematoxylin solution for $2 \mathrm{~min}$.

Immunohistochemistry was performed to visualize the VDR and $\mathrm{H}, \mathrm{K}-\mathrm{ATPase} \beta$ $(\mathrm{HK} \beta)$. Briefly, $1 \%$ bovine serum albumin (blocking reagent) was used to incubate the sections for $1 \mathrm{~h}$ at room temperature. It was then incubated overnight at $4{ }^{\circ} \mathrm{C}$ with an anti-VDR rat polyclonal antibody (ab115495, dilution 1:150, Abcam, Cambridge, UK) and anti-HK $\beta$ rabbit polyclonal primary antibody (ab176992, dilution 1:100, Abcam, Cambridge, $\mathrm{UK})$. Goat anti-rat IgG $(\mathrm{H}+\mathrm{L})$ antibodies, which were conjugated with Biotin-SP (112065-003, dilution 1:1000, Jackson Immunoresearch, West Grove, PA, USA), and goat antirabbit IgG H\&L (TRITC) (ab6718, Abcam) antibodies were then added and incubated at room temperature $\left(22{ }^{\circ} \mathrm{C}\right)$ for $1 \mathrm{~h}$. The phosphate-buffered saline (PBS) was used to wash the sections, which then were incubated with blocking reagent ExtrAvidin ${ }^{\circledR}$ Peroxidase (Thermo Fisher Scientific, Waltham, MA, USA) at a 1:1000 dilution ratio at room 
temperature. The PBS was then used for washing. The sections were then treated with $3,3^{\prime}$-diaminobenzidine in urea (1:1) for $6 \mathrm{~min}$ and counterstained with hematoxylin.

The immunostaining with 5-bromo-2'-deoxyuridine (BrdU) was performed on VDD, SDL and SDD mice $(n=5)$ that had been injected with $120 \mathrm{mg} / \mathrm{kg}$ body weight of BrdU (B5002, Sigma Aldrich, St. Louis, MO, USA) intraperitoneally $2 \mathrm{~h}$ before euthanasia. The monoclonal mouse antibodies, anti-BrdU (MI-11-3, dilution 1:500, MBL Life Science, Woburn, MA, USA), were then used to incubate the sections at $4{ }^{\circ} \mathrm{C}$ for $1 \mathrm{~h}$ followed by incubation for $1 \mathrm{~h}$ with goat anti-mouse IgG $(\mathrm{H}+\mathrm{L})$, biotin-SP-conjugated (115-065-003, Jackson Immunoresearch, dilution 1:500).

Antigen retrieval was performed with co-immunofluorescence staining using a citrate buffer for $20 \mathrm{~min}$ at $96^{\circ} \mathrm{C}$. The tissue sections were incubated in $0.1 \%$ Triton X-100 in PBS followed by a $1 \mathrm{~h}$ blocking reaction with $1 \%$ bovine serum albumin and incubation overnight at $4{ }^{\circ} \mathrm{C}$ with a rat primary antibody, anti-VDR (ab115495, dilution 1:150, Abcam). The PBS was used to wash the sections and then treated with Alexa Fluor 448 or Cy3-conjugated goat anti-rat secondary antibodies (112-545-003 or 112-165-003, Jackson ImmunoResearch, dilution 1:500) for $1 \mathrm{~h}$ at room temperature. The sections were washed with PBS solution and incubated with rabbit anti-HK $\beta$ (parietal cell marker) and then with goat anti-rabbit secondary antibodies as described above. Several anti-VDR incubated tissue sections were also incubated with lectins specific for surface mucous cells (Ulex europaeus agglutinin I or UEA-1) or mucous neck cells (Griffonia simplicifolia II or GSII) that were conjugated with rhodamine or fluorescein, respectively (RL-1062 or L21415, Life Technologies, Carlsbad, CA, USA).

4',6-diamidino-2-phenylindole (ab104139, Abcam) was used as a mounting medium and as nuclear counterstaining section sample preparations. Negative controls for each experiment excluded primary antibodies.

\subsection{RNA Separation and cDNA Synthesis}

An RNeasy Mini Kit (Qiagen, Hilden, Germany) was used to collect total RNA from different parts of the stomachs of the mice (forestomach, corpus and antrum) using the manufacturer's directions. RNA purification was performed using an RNase Free DNase kit (Qiagen). The cDNA was synthesized by reverse transcribing $1 \mu \mathrm{g}$ RNA using the iScript ${ }^{\mathrm{TM}}$ cDNA synthesis kit (Bio-Rad, Hercules, CA, USA) following the manufacturer's protocol.

\subsection{Reverse Transcription PCR (RT-PCR)}

The expression patterns of Cyp2r1, Vdr, Cyp27b1, Cyp24a1 and Cyp27a1 in the gastric tissue of normal mice were analyzed. A GoTaq Flexi DNA polymerase kit (Promega, Madison, WI, USA) was used to conduct the RT-PCR with cDNA using the manufacturer's instructions and the primers are shown in Table S1. Gel electrophoresis was used to separate PCR products with ethidium bromide in $2 \%$ agarose and visualized with a Gel Doc $^{\mathrm{TM}}$ EZ Imager (Bio-Rad).

\subsection{Quantitative Real-Time PCR ( $q$ RT-PCR)}

Quantitative real-time PCR (qPCR) using a QuantiStudio ${ }^{\circledR} 5$ Real-Time PCR instrument (Applied Biosystems, Foster City, CA, USA) was used for the differential expression of genes specific for gastric epithelial cell lineages, cell proliferation or direct target VDR genes. Green dye SYBR was employed for the quantitation of double-stranded DNA after an individual cycle. The Supplementary Data Table S1 lists the primers used. Reactions with 40 amplification cycles were performed with each cycle including denaturation for $15 \mathrm{~s}$ at $95{ }^{\circ} \mathrm{C}$, annealing for $1 \mathrm{~min}$ at $60^{\circ} \mathrm{C}$ and extension for $15 \mathrm{~s}$ at $95^{\circ} \mathrm{C}$. The melt curve stage was performed at $60^{\circ} \mathrm{C}$ followed by dissociation for $1 \mathrm{~s}$ at $95^{\circ} \mathrm{C}$. The samples were tested in triplicate and the expressions of gene levels were measured using the comparative cycle threshold method ( $\Delta \Delta \mathrm{CT}$ method). The expression was then normalized to Gapdh. 


\subsection{Mass Spectrometric Measurement of Serum Vitamin D}

Blood samples were obtained immediately by a cardiac puncture technique in anaesthetized animals. Approximately $1 \mathrm{~mL}$ of blood was collected into BD vacutainers (Ref. 367957; BD Biosciences, Franklin Lakes, NJ, USA). Centrifugation was used at $906 \times g$ (3500 rpm) for $15 \mathrm{~min}$ at $4{ }^{\circ} \mathrm{C}$ to separate the serum and then stored at $-80^{\circ} \mathrm{C}$. The analysis of serum $25(\mathrm{OH}) \mathrm{D}$ required the calculation of the total concentration of $25(\mathrm{OH}) \mathrm{D}$, which is the sum of $[25(\mathrm{OH}) \mathrm{D} 3+25(\mathrm{OH}) \mathrm{D} 2]$. Liquid chromatography coupled to tandem mass spectrometry (LC-MS/MS) was performed to quantify 25(OH)D3 and 25(OH)D2. This was followed by adding an internal standard 25(OH)D3(6,9,9-D3) to each sample and vortex mixing for $1 \mathrm{~min}$. One milliliter of hexane in ethyl acetate $(9: 1 ; v / v)$ was then added to each sample for liquid-liquid extraction (LLE). This sample was centrifuged at $3000 \times g$ for $30 \mathrm{~min}$ and the top organic layer was stored whereas the lower layer was further extracted by adding another round of hexane and ethyl acetate $(9: 1 ; v / v)$ and centrifuging two more times. The extracts from all three samples were pooled together and dried using N2 gas at room temperature in a sample concentrator (Stuart sample concentrator model no SBHCONC/1, Stuart Equipment's, Staffordshire, UK). Calibrants containing the spiked samples at a known concentration were used to prepare the calibration curve. Quality controls composed of spiked samples prepared at a known concentration at three different levels were processed using the same LLE along with the samples. Finally, the dried residue was resuspended using a mixture of methanol/water $(75: 25, v / v)$. The samples were analyzed using the Ultra High Pressure Liquid Chromatography (UHPLC) system coupled to a tandem mass spectrometer, model 8060 system (Shimadzu, Kyoto, Japan).

\subsection{Measurement of Gastric Acid}

Stomachs harvested from SDL, SDD and VDD mice were cut up along the greater curvature. A total of $1 \mathrm{~mL}$ of $0.9 \% \mathrm{NaCl}(\mathrm{pH} 7.0)$ was used to rinse the stomachs and centrifuged at $1848 \times g$ for $10 \mathrm{~min}$. This was followed by the collection of the supernatant. The $\mathrm{H}^{+}$concentration was quantified by performing manual titrations that compared the supernatant concentration with the $0.005 \mathrm{M} \mathrm{NaOH}$. Finally, these results were then normalized to the weights of their bodies.

\subsection{Statistical Analysis}

GraphPad Prism 7.0.3 (GraphPad, Inc., San Diego, CA, USA) was used for the statistical analysis. A one-way analysis of variance (ANOVA), Student's $t$-tests or Dunnett's multiple comparisons post-test were used for the data analysis as required. Data were presented as the means \pm standard deviation (SD) and the results were considered significant if $p$-values $<0.05$.

Fiji-ImageJ software (version 1.52n, Tokyo, Japan) was used for the analysis to enumerate BrdU-labeled cells and parietal cells as well as to measure the HK $\beta$ pixel intensity.

\section{Results}

\subsection{Expression of the VDR in Normal Gastric Epithelial Tissues}

The distribution of the VDR in normal mouse stomachs was determined; VDR-specific antibodies were used for immunolocalization (Figure 1). We observed the binding of VDR antibodies along the forestomach and epithelial lining of the corpus (Figure 1c,d). Cells in all of the parts of the gastric gland of the corpus including the pit, isthmus, neck and base expressed the VDR. VDR localization was primarily nuclear with occasional cytoplasmic expression (Figure 1d insert, arrow and arrowhead). PCR detection of $V d r$ expression confirmed that $V d r$ was expressed in the forestomach and corpus regions as well as the pyloric antrum of the stomach (Figure 1e). 

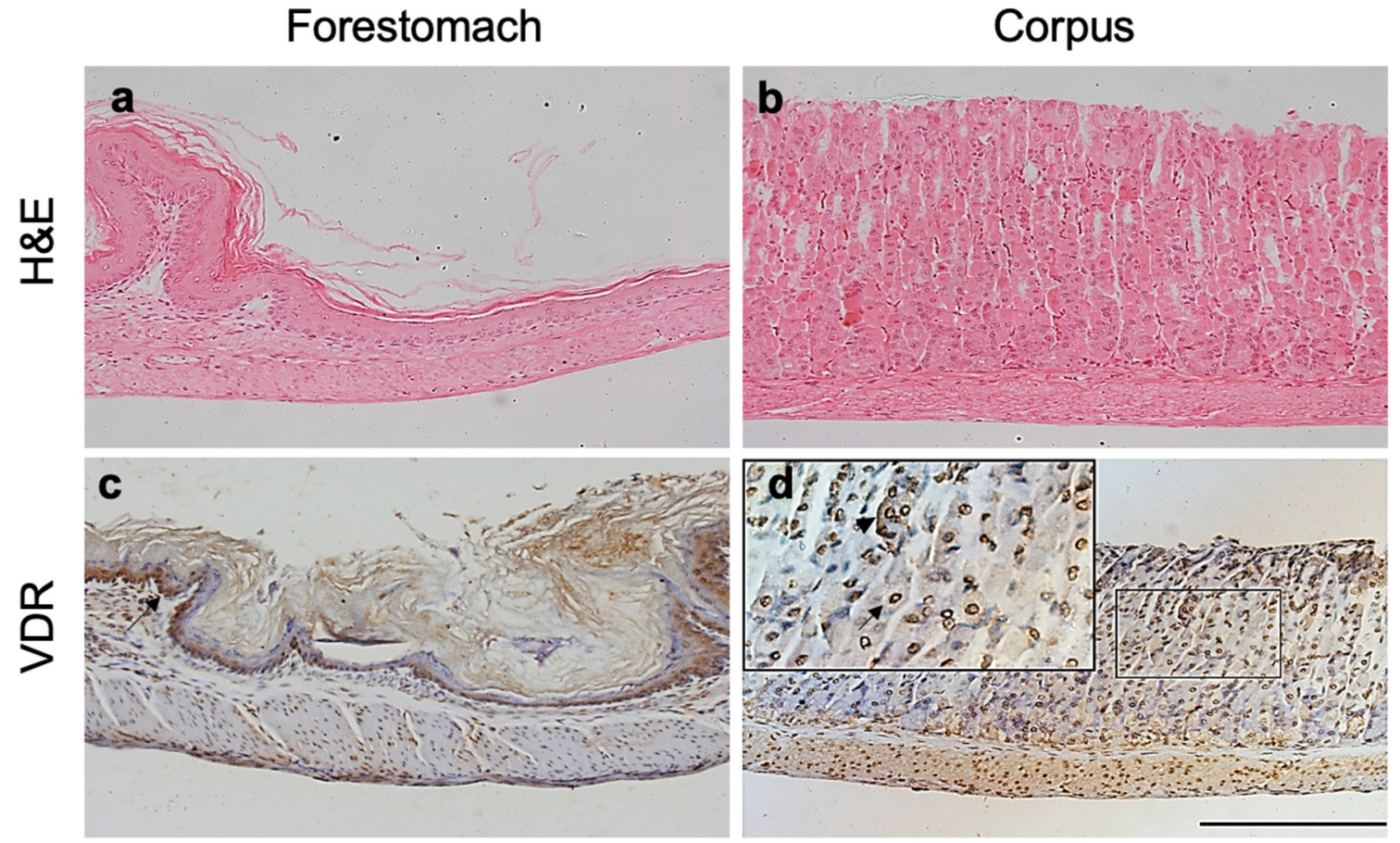

\section{Corpus}
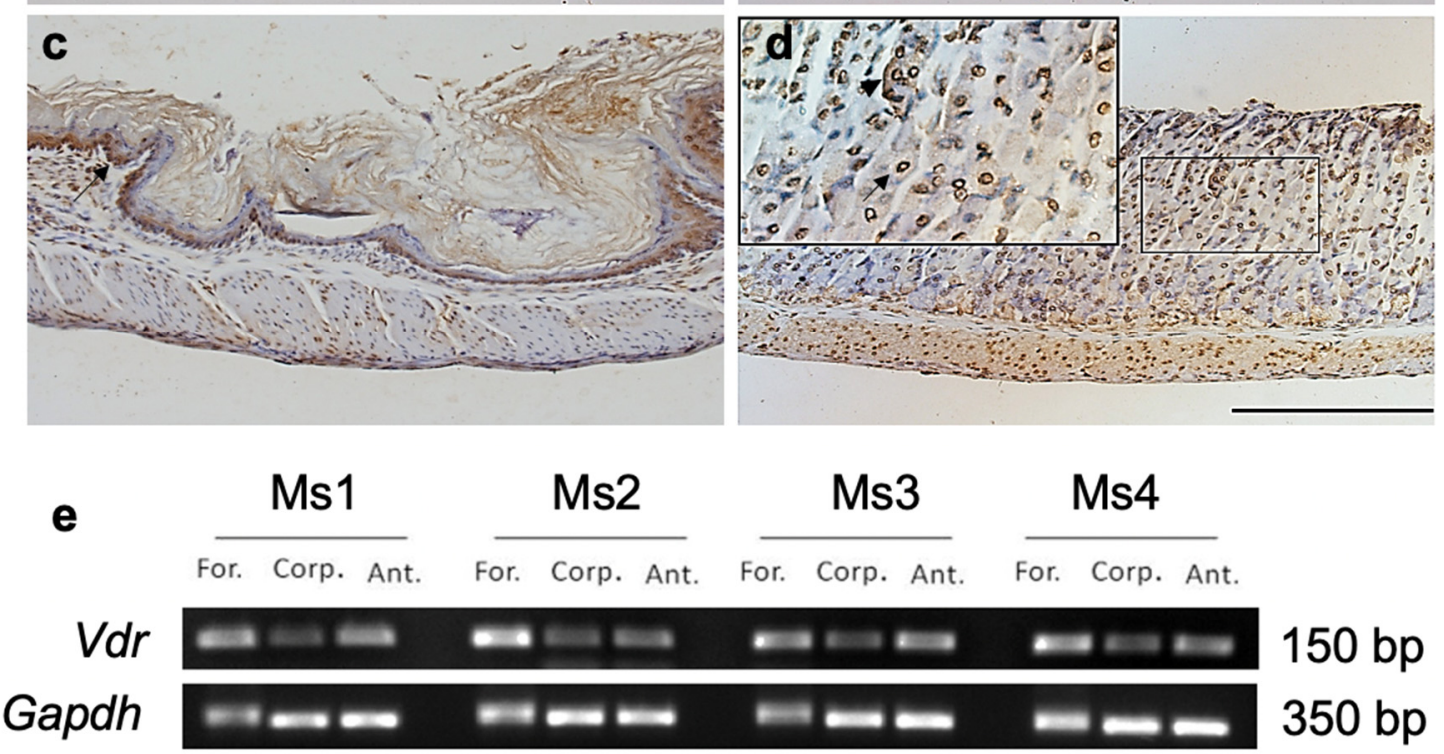

Figure 1. VDR expression in murine stomachs. H\&E staining of the (a) forestomach and (b) corpus and the immunoperoxidase analysis of adult normal mouse stomachs (2-4 months old, $n=4)$ using a rat polyclonal anti-VDR antibody showing positive signals in both the (c) forestomach and (d) corpus. VDR expression was observed primarily in the nucleus ((c), arrow) with an occasional cytoplasmic expression ((d), arrowhead). Scale bar, $200 \mu \mathrm{m}$. (e) Qualitative PCR analysis of $V d r$ expression in four adult normal mice (Ms1-4) produced bands in the forestomach (For.), corpus (Corp.) and antrum (Ant.) with the most intense bands observed in the forestomach. Gapdh was used as an internal control, full figure please see Supplementary Materials File 1.

\subsection{The VDR Is Expressed by Gastric Parietal and Mucous Cells}

To determine which gastric epithelial cells express the VDR and therefore respond to $\mathrm{VD}_{3}$, immunofluorescent staining was performed on tissue sections from normal mice. The VDR antibody was colocalized with the parietal cell-specific marker, HK $\beta$ (Figure 2a-c). The colocalization of the VDR was also observed with UEA-1-labeled (Figure 2d-f) and GSII-labeled (Figure 2g-i) surface mucous cells and mucous neck cells, respectively.

\subsection{Gastric Expression of CYP Enzymes Involved in Regulating $V D_{3}$}

Cytochrome P450 enzymes regulate the expression of serum $\mathrm{VD}_{3}$. These enzymes are expressed in the kidney and liver and are involved in both $\mathrm{VD}_{3}$ activation (CYP2R1, CYP27A1 and CYP27B1) and degradation (CYP24A1). To determine if these enzymes are expressed in the stomach, a PCR analysis was performed (Figure 3). Cyp2r1, Cyp27a1 and Cyp27b1 were expressed in all regions of the stomach with the highest levels in the forestomach. In contrast, the expression of Cyp24a1 was detected only in the forestomach (Figure 3). 

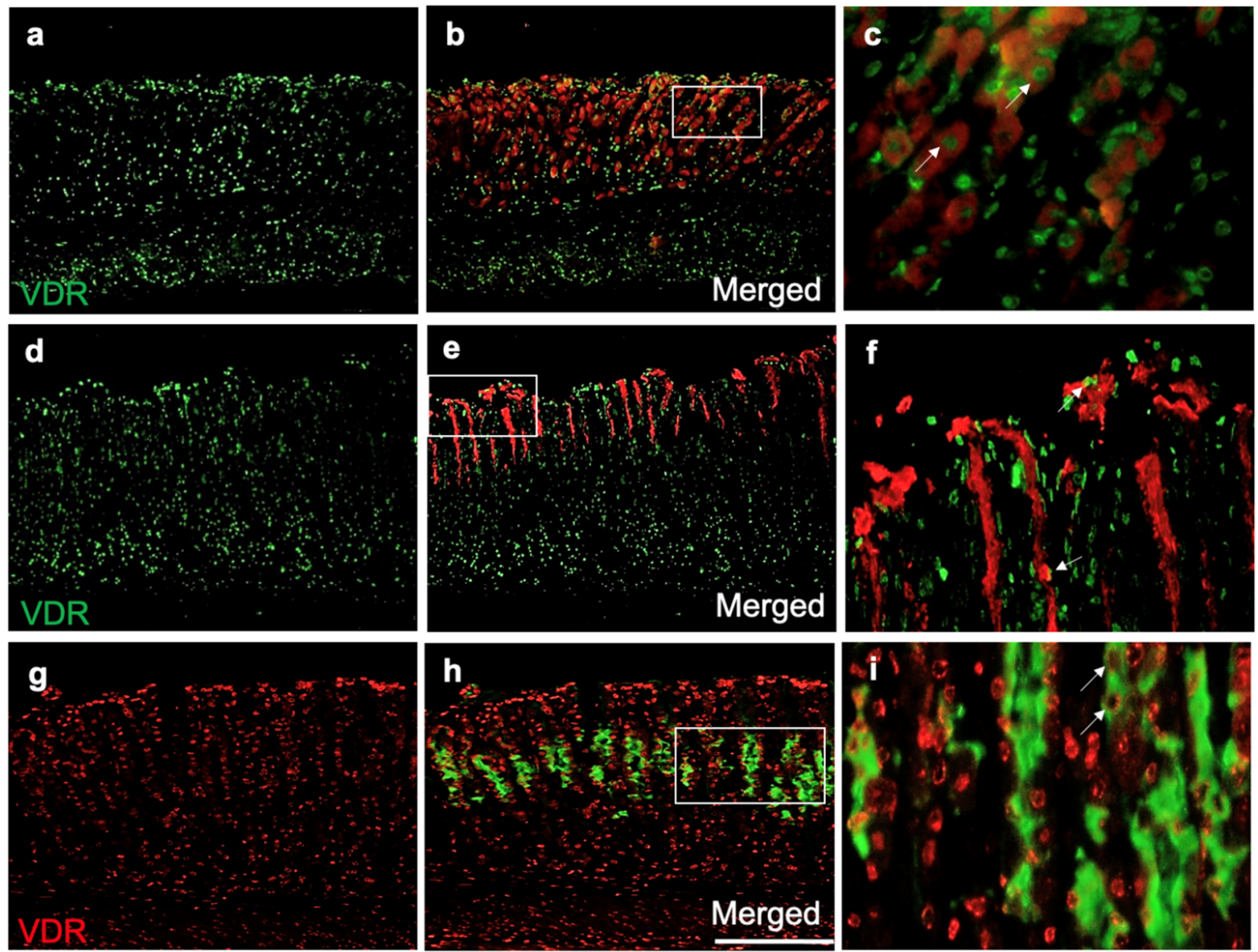

Figure 2. Expression of the VDR in the gastric epithelial cells of 2-4-month-old mice. (a,d,g) Anti-VDR antibody colocalized with (b) a parietal cell-specific HK $\beta$ antibody, (e) surface mucous cell-specific UEA-1 lectin and (h) mucous neck cell GSII lectin. Scale bar, $200 \mu \mathrm{m}$. VDR expression in (c) parietal cells, (f) surface mucous cells and (i) mucous neck cells. Scale bar, $100 \mu \mathrm{m} . n=3$.

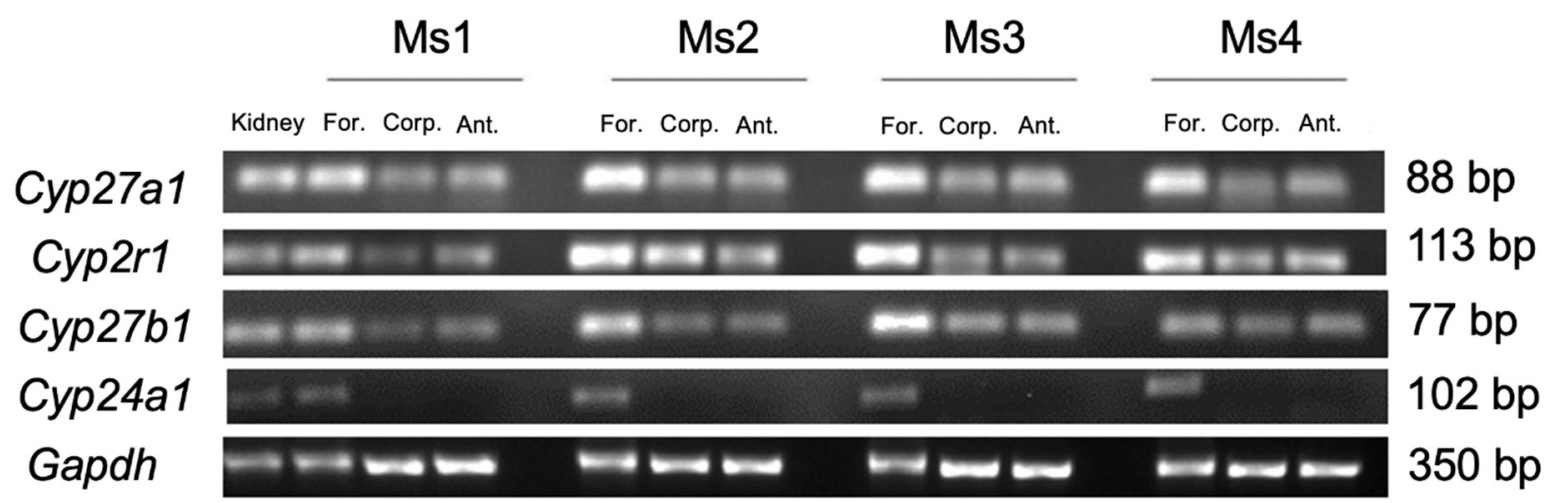

Figure 3. CYP enzyme expression in the stomachs of four 2-4-month-old normal mice $(n=4)$. Cyp2r1, Cyp27a1 and Cyp27b1 were expressed in the forestomach (For.), corpus (Corp.) and antrum (Ant.) with the highest expression observed in the forestomach. Cyp24a1, which is responsible for VD degradation, was expressed only in the forestomach. Kidney RNA and Gapdh were used as positive controls and internal controls, respectively.

\subsection{Establishment of a VDD Mouse Model}

To understand the nutritional role of VD in gastric cell homeostasis, a specific diet deficient in VD was provided to mice. This very low VD-supplemented diet was selected to avoid negative feedback consequences such as high serum calcium and phosphate. All mice tolerated the diets well. The serum levels of total $25(\mathrm{OH}) \mathrm{D}$ and $\left[25(\mathrm{OH}) \mathrm{D} 3+25(\mathrm{OH}) \mathrm{D}_{2}\right]$ 
were quantified. The Holick classification for VD deficiency in humans was followed [33]; specifically, VD deficiency was considered to be $25(\mathrm{OH}) \mathrm{D}<20 \mathrm{ng} / \mathrm{mL}$, insufficiency of $25(\mathrm{OH}) \mathrm{D}$ was defined as a concentration between $21-29 \mathrm{ng} / \mathrm{mL}$ and an optimal level of $25(\mathrm{OH}) \mathrm{D}$ was considered to be $25(\mathrm{OH}) \mathrm{D}>30 \mathrm{ng} / \mathrm{mL}$.

Body weights were assessed for 3 months; there was a slight increase observed in the VDD group when compared with the control mice. This finding was not in agreement with a previous study that reported VD deficiency was associated with obesity [34]; however, there was no significant difference between this and the control group ( $p$-value $>0.05$, Figure $4 a$ ). Serum $25(\mathrm{OH}) \mathrm{D}$ was reduced from $33.14 \mathrm{ng} / \mathrm{mL}$ in the control group to $6.81 \mathrm{ng} / \mathrm{mL}$ in the $\mathrm{VDD}$ group due to the lower $\mathrm{VD}_{3}$ dietary intake for 3 months. Interestingly, our results showed that VD insufficiency $(24.18 \mathrm{ng} / \mathrm{mL}$ ) could be produced in mice by removing the overhead light only (normal diet) to prevent the production of endogenous VD (Figure $4 \mathrm{~b}$ ). We also found that none of the mice in any of the groups expressed any signs of hair loss or reduced physical activity and all mice behaved normally.

a

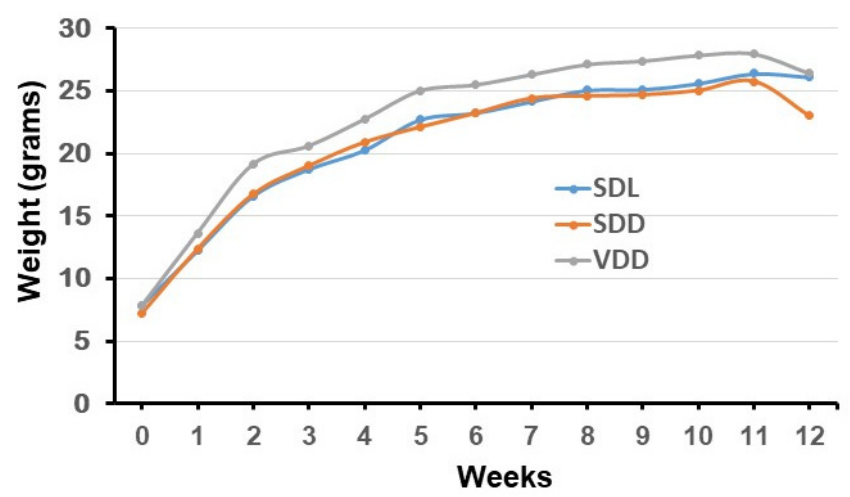

b

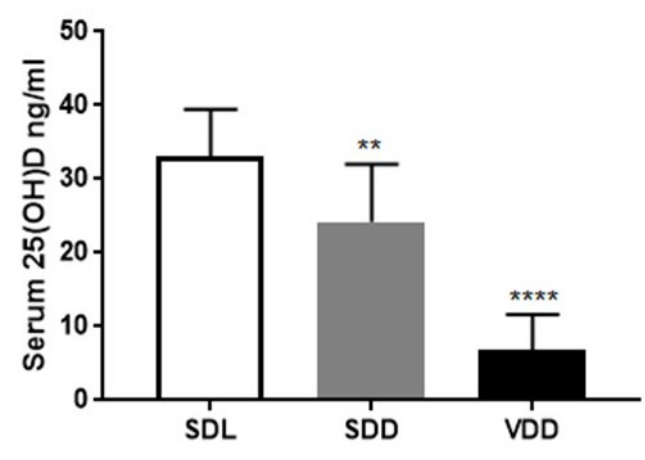

Figure 4. Effect of a VD-deficient diet on weight and VD serum levels. Diets containing 25 IU/kg-VD3 (VD3, deficient diet) or $1000 \mathrm{IU} / \mathrm{kg}$ (standard diet) were administered to approximately 4-month-old mice ( $n=7 /$ group) to assess their effects on serum 25(OH)D and weight. (a) VDD mice gained more weight than the controls. (b) VDD mice exhibited a significant reduction in $25(\mathrm{OH}) \mathrm{D}$ serum concentration presented as the mean $(\mathrm{ng} / \mathrm{mL}) \pm \mathrm{SD}$. A one-way ANOVA was used for the serum 25(OH)D analysis and a two-way ANOVA was performed for the weight analysis. ${ }^{* *} p<0.01,{ }^{* * * *} p<0.0001$.

\subsection{Low Gastric Acid Content along with Increased Gastrin Gene Expression in the VDD Stomach}

After establishing that the VDR was expressed at high levels in the normal stomach tissue, we examined the effects of the deficiency of VD on the gastric target cells of VD, as shown in Figure 5. A microscopic examination of the H\&E stained sections of the gastric mucosa revealed no apparent differences in mucosal tissue thickness or overall tissue organization (Figure 5a) except that the parietal cells appeared slightly smaller in the VDD mice than in the controls (Figure 5b). However, the parietal cells exhibited similar HK $\beta$ staining in all groups (Figure $5 \mathrm{~d}$,e). Alternatively, the mRNA expression of Atp $4 a$ and $A t p 4 b$ was significantly downregulated ( $p=0.0001$ and 0.0083 , respectively) in VDD mice compared with control mice (Figure $5 \mathrm{f}, \mathrm{g}$ ). Although we did not see any statistically significant difference, the gastric contents of $\mathrm{H}^{+}$in the SDL and SDD groups were greater than the VDD group, as shown in Figure 5i.

It is established that gastrin regulates the secretion of acid by parietal cells [35]; therefore, the mRNA expression of gastrin was also quantified. Unexpectedly, the relative expression of Gast mRNA was significantly upregulated four-fold $(p=0.0174)$ in the VDD group relative to the control group. However, the SDD group did not exhibit a significant upregulation of Gast expression in the antral tissues (Figure 5h). 


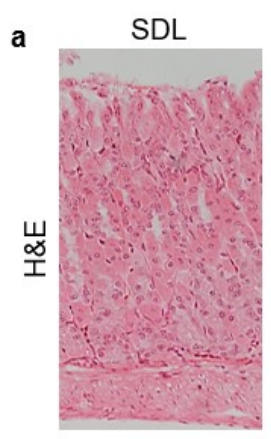

b

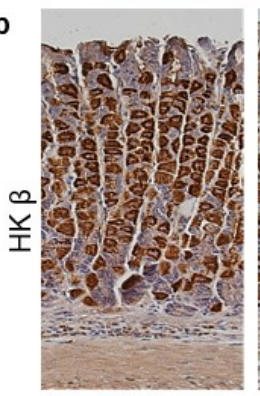

VDD
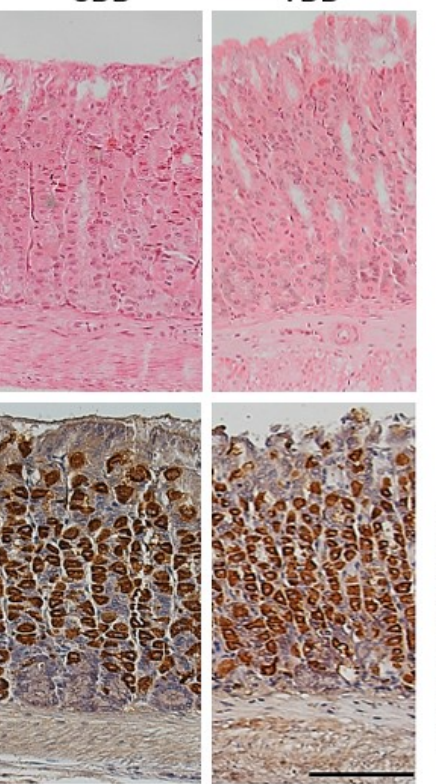

f

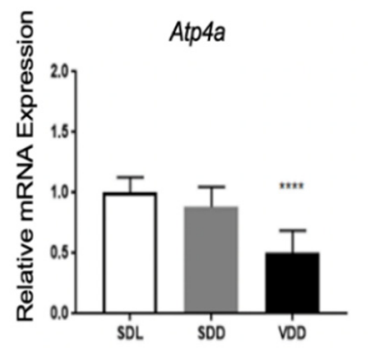

h

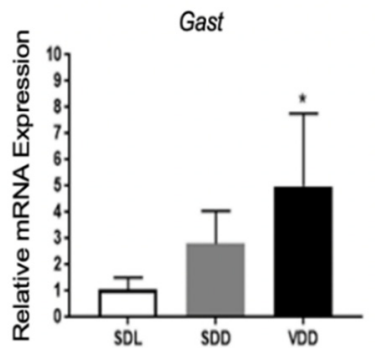

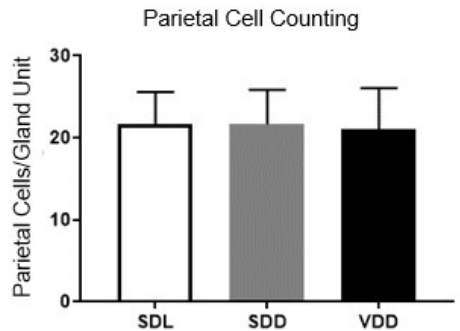

d

HKß Intensity: SDL vs SDD
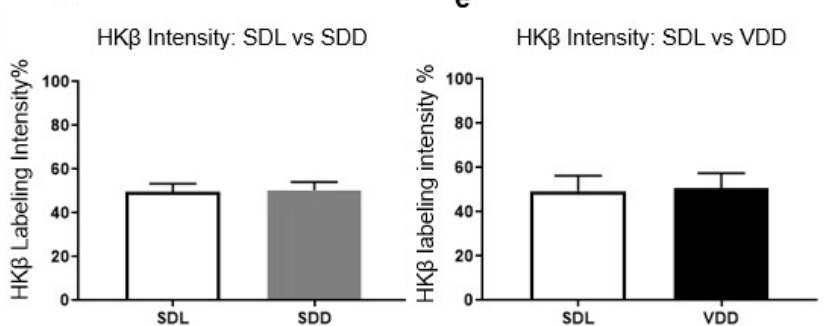

g

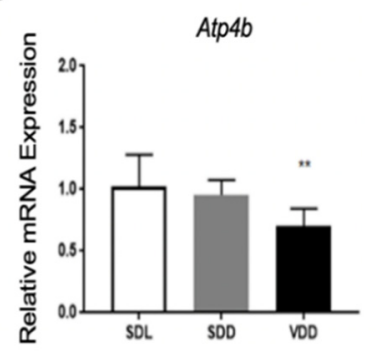

i

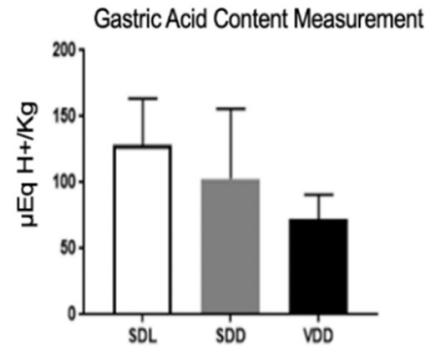

Figure 5. Gastric acid content is reduced in VD-deficient mouse stomachs. (a) H\&E staining of the gastric mucosae of SDL, SDD and VDD mice. (b) Immunohistochemical detection of parietal cell-specific HK $\beta$. No change was observed in the (c) number of parietal cells or intensities of HK $\beta$ antibody staining in either the (d) SDD and (e) VDD groups compared with the SDL control group. Scale bar, $200 \mu \mathrm{m}$. A significant decrease in (f) Atp $4 a$ and (g) Atp $4 b$ expression was observed in the VDD group compared with the SDL controls. (h) Gast expression increased while (i) gastric acid content decreased slightly in VD-deficient mice compared with those in the control mice. All mice were approximately 4 months old ( $n=7 /$ group). A one-way ANOVA and Student's $t$-tests were used for the analysis of the data. ${ }^{*} p<0.05,{ }^{* *} p<0.01,{ }^{* * * *} p<0.0001$.

\subsection{A Noticeable Increase in Gastric Stem/Progenitor Cell Proliferation in the VDD Group of Mice}

BrdU immunolabeling was performed to test whether a high gastrin expression in the stomachs of VDD mice was associated with a change in stem cell proliferation in the gastric mucosa. Proliferating cells were quantified by calculating an average number of positive BrdU cells in the corresponding locations of the gastric mucosal histological sections. This demonstrated an increase in the stem cell proliferation in the isthmus region of the corpus 
gastric gland in VDD and SDD mice compared with the controls $(p=0.029$ and 0.025 , respectively; see Figure 6).

a

SDL

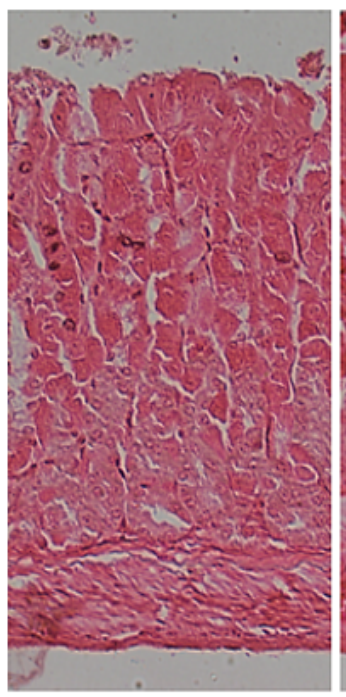

SDD

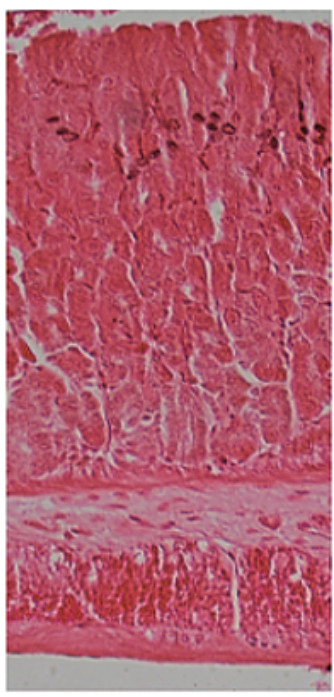

b

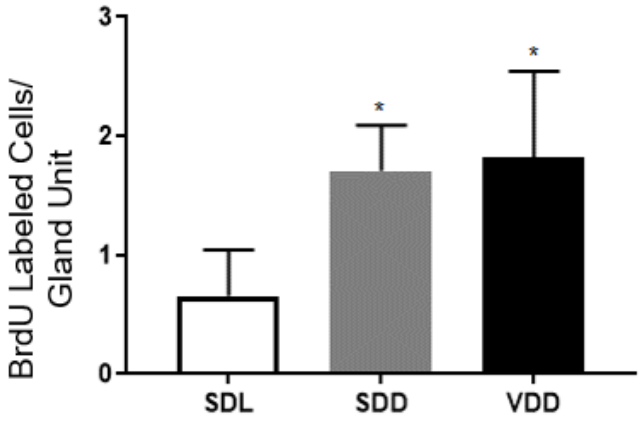

Figure 6. VD deficiency is associated with an increased proliferation. (a) Immunohistochemical analysis of BrdU-labeled proliferating cells in the isthmus domain of the corpus gastric gland ( $n=4$ /group). Scale bar, $200 \mu \mathrm{m}$. (b) Increased BrdU-label in the SDD and VDD groups compared with the SDL group. The data analysis was performed using a one-way ANOVA, ${ }^{*} p<0.05$.

\subsection{Gastric Differentiation Markers and Vdr Expression Are Affected by Vitamin D Status}

No change was observed in the PAS staining carried out on the surface mucous cells in the gastric tissue samples between the three treatment groups (Figure 7a). To examine the regulatory effect of $\mathrm{VD}_{3}$ on the $V d r$ transcription and gastric epithelial cell lineage-specific genes and targeted genes of $1 \alpha, 25(\mathrm{OH})_{2} \mathrm{D}_{3}$ ( $(21$, Pthlh and Trpv6), RNA extracted from the corpus region was used to carry out $\mathrm{qPCR}$. In mice with $\mathrm{VD}_{3}$-deficient diets, the expression of $V d r$ mRNA decreased ( $p=0.05$ ) compared with the control mice group (Figure $7 b)$. We then investigated the mucous cells in the gastric epithelia in mice with low and normal levels of serum VD by analyzing and comparing the relative expression of Muc6 and Muc5ac markers for mucous neck cells and surface mucous cell, respectively. We found a small but not statistically significant reduction in the transcription levels of the two important genes in VDD and SDD mice compared with SDL mice (Figure 7c,d). However, the expression of If, which is specific for chief cells, was significantly downregulated $(p=0.0309)$ in the VDD group when compared with the control (Figure 7e).

\subsection{The Expression of the Target Genes of $1 \alpha, 25(\mathrm{OH})_{2} \mathrm{D}_{3}$ in Response to Vitamin D Status}

The transcription of several genes is regulated by $1 \alpha, 25(\mathrm{OH})_{2} \mathrm{D}_{3}$ through the binding of VDRE to the promoters of target genes such as Trpv6, Pthlh and $p 21$. Previously, these genes were reported to be expressed in the stomach $[8,10,14]$. We found that within the gastric mucosa of VDD mice, the relative mRNA expression of these genes was moderately downregulated when compared with the SDL control mice group (Figure 8a-c). Lastly, it was only possible to detect a statistically significant downregulation for Pthlh expression. 
a

SDL

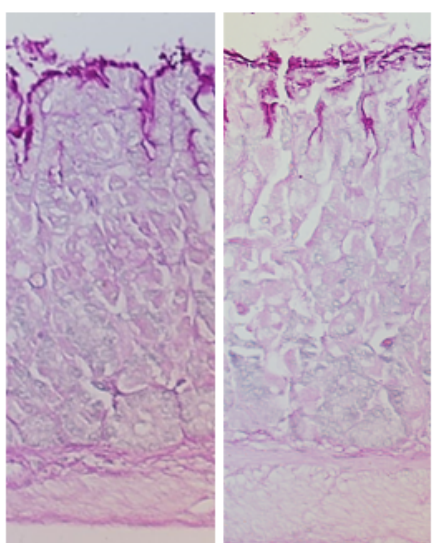

VDD

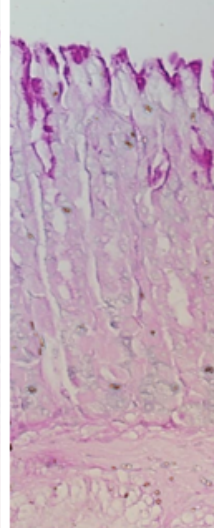

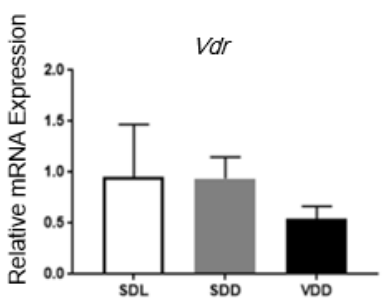

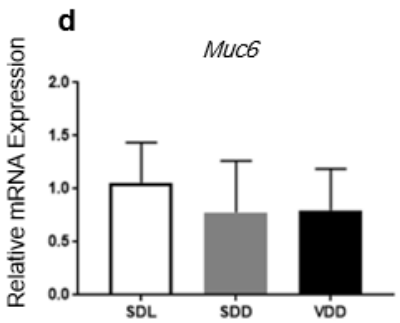

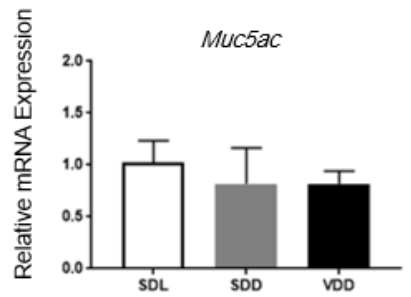

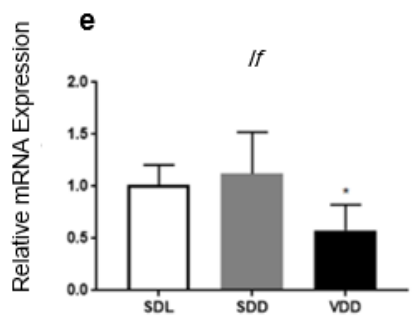

Figure 7. PAS staining and expression of cellular differentiation markers in VD-deficient mice. (a) No apparent difference in the PAS staining of gastric mucosa. RNA was obtained from the corpus regions of SDD, SDL and VDD mice ( $n=7 /$ group) to evaluate the expression of representative genes by qPCR. Relative mRNA expression of (b) $V d r$, (c) Muc5ac, (d) Muc6 and (e) If. If only showed a significant decrease in VD-deficient mice when compared with the controls. The data analysis was performed using a one-way ANOVA, ${ }^{*} p<0.05$.

a
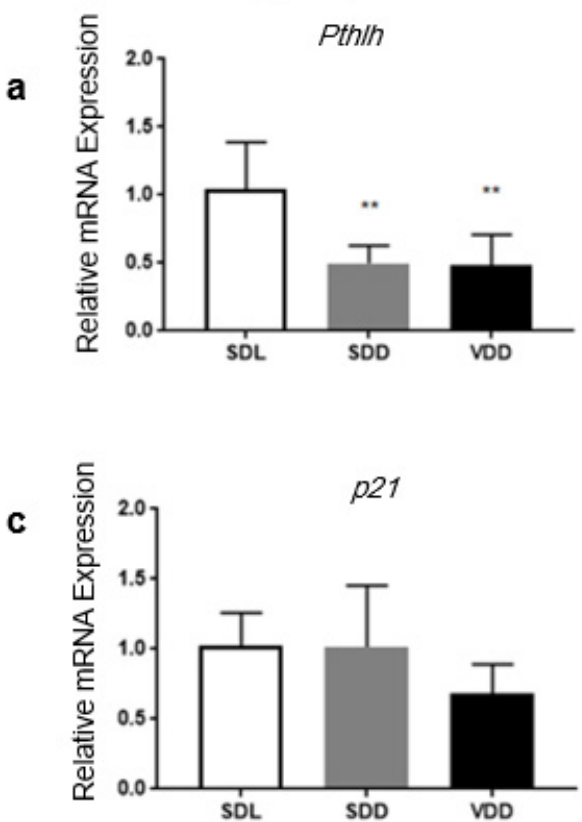

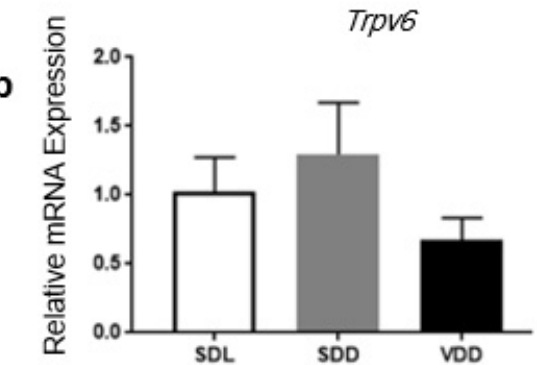

SDL

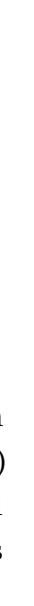


tected [16]. In the current study, we demonstrated that the VDR is expressed in different parts of the gastric epithelial tissues. Although Stumpf et al., using autoradiography, found that only chromaffin cells and mucous neck cells of the gastric glands are targets for $1 \alpha, 25(\mathrm{OH})_{2} \mathrm{D}_{3}$ [16], our immunohistochemical analysis revealed a wider cellular scattering of the VDR along the corpus gastric glands including mucous neck cells, surface mucous cells and parietal cells.

We also observed that the expression of both $V d r$ and Cyp genes is involved in the breakdown and synthesis of $1 \alpha, 25(\mathrm{OH})_{2} \mathrm{D}_{3}$. These genes were expressed in separate parts of the stomach with the antrum and corpus gastric glands explicitly expressing Cyp27a1, Cyp2r1 and Cyp27b1, which encode the enzymes responsible for producing $1 \alpha, 25(\mathrm{OH})_{2} \mathrm{D}_{3}[5,39,40]$, suggesting that these two regions of the gastric epithelia can locally generate biologically active $\mathrm{VD}_{3}$. It has also been reported that $C y p 24 a 1$, which encodes a protein that is responsible for inactivating $1 \alpha, 25(\mathrm{OH})_{2} \mathrm{D}_{3}$ [41], is regulated in a negative feedback loop by $1 \alpha, 25(\mathrm{OH})_{2} \mathrm{D}_{3}$ through the attachment of VDRE to the promoter region of Cyp24a1 [42]. Our study demonstrated that the Cyp24a1 expression is exclusively evident in the forestomach (Figure 3), suggesting an important role of the forestomach in the degradation of $1 \alpha, 25(\mathrm{OH})_{2} \mathrm{D}_{3}$ and the monitoring of $\mathrm{VD}_{3}$ local levels.

We investigated the impact of VD deficiency on gastric acidity as well as gastric epithelial cell proliferation and differentiation. It is well known that, in parietal cells, HK-ATPase is responsible for the secretion of acid by exchanging $\mathrm{H}^{+}$for $\mathrm{K}^{+}$. Moreover, the gastrin hormone regulates the acid secretion of parietal cells [43]. Herein, we report a reduction in gastric acidity, a decrease in mRNA expression of Atp $4 b$ and Atp $4 a$ and an increase in the expression of Gast mRNA in VD-deficient mice. Interestingly, Antico et al. found a correlation between low $25(\mathrm{OH}) \mathrm{D}_{3}$ serum concentrations and the development of autoimmune-gastritis (AIG) in an Italian study population [44]. They further showed that the deficiency of vitamin D is a risk factor for AIG [44], which results from the production of autoantibodies produced against $\mathrm{HK}$ and decreased acid secretion and causes inflammation in gastric mucosa. The advanced stage of the disease finally causes mucosal atrophy [45]. Our data are consistent with those reported by Antico et al., which showed that low $25(\mathrm{OH}) \mathrm{D}_{3}$ levels may be a predisposing factor for decreased gastric acid secretion and AIG development.

We also observed that VD-deficient mice showed a significant increase in the proliferation of gastric stem cells (Figure 6). An increased cell proliferation in parathyroid glands has also been reported in rats administered a VD-deficient diet for 3 weeks [46]. Additionally, the colons of $V d r$ knockout mice revealed a significant upregulation in the expression of proliferating cell nuclear antigen (PCNA) when compared with the wild type mice [47]. Collectively, these results indicate the significance of the VDR and vitamin D in regulating cell proliferation. Furthermore, higher levels of proliferation in gastric stem/progenitor cells within VD-deficient mice correlates with increased gastrin expression levels as gastrin is a trophic hormone that stimulates proliferation $[48,49]$.

We examined the changes in the relative mRNA expression of Muc5ac, Muc6 and If, which are specific for surface mucous, mucous neck and chief cells, respectively. As the serum concentrations of $25(\mathrm{OH}) \mathrm{D}_{3}$ were changed in the different study groups, finding a mild downregulation in the expression of all of these differentiation markers was expected. However, we were only able to detect a statistical significance for If.

The VDR has been reported to regulate the transcription of the $\mathrm{VD}_{3}$ target genes by the binding of VDRE to their promoters [8]. Trpv6, a calcium channel, is expressed in the stomach and plays an important role in $\mathrm{Ca}^{2+}$ homeostasis in the GI tract $[10,11] . P 21$ and Pthlh are also $1 \alpha, 25(\mathrm{OH})_{2} \mathrm{D}_{3}$ target genes that are expressed in the stomach. PTHLH is regulated by gastrin and it is a growth factor regulator [50] while p21 is a tumor suppressor that causes cell cycle arrest [14]. We found a statistically significant decrease in Pthlh in the VD-deficient mice when compared with the control mice (Figure 8). The true role of Pthlh in the stomach is yet to be discovered. 


\section{Conclusions}

This study revealed and highlighted the importance of VD in a normal stomach. The gastric epithelial parietal and both types of mucus-secreting cells were identified as responsive to VD. Moreover, mice on a VD-deficient diet for 3 months showed lower gastric acid contents and a higher gastrin hormone expression as well as increased cellular proliferation rates. These reported results suggest that the VDR and VD play a significant role in maintaining gastric epithelial stem cell proliferation and differentiation. This work improves our understanding of the relationship between VD deficiency and gastric diseases such as cancer. More research will be required to characterize the behavior of similar genes and proteins in humans with VD deficiency during the multistep process of gastric carcinogenesis.

Supplementary Materials: The following are available online at https:/ /www.mdpi.com/article/10 $.3390 /$ biology10080705/s1, Table S1: Oligonucleotide primers for the amplification of $V d r$ and Cyp. File 1: Original figures.

Author Contributions: Conceptualization, A.A.M., S.M.K. and I.S. Methodology, A.A.M., S.M.K., I.S. and S.M. Validation, A.A.M., S.M.K., I.S. and S.M. Investigation, A.A.M., S.M.K. and I.S. Resources, A.A.M. Writing and original draft preparation, I.I.A. Writing revisions and editing, I.I.A., A.A.M., S.M.K. and I.S. Supervision, A.A.M., S.M.K. and I.S. Project administration, A.A.M. Funding Acquisition, A.A.M., S.M.K. and I.S. All authors have read and agreed to the published version of the manuscript.

Funding: This work was supported by the Zayed Center for Health Sciences, United Arab Emirates University UAEU, Center-Based Interdisciplinary (grant number 31R138).

Institutional Review Board Statement: The study was conducted according to the international standards of animal use and was approved by The Animal Research Ethics Committee (A-REC) of United Arab Emirates University (Protocol\# ERA_2017_5684).

Informed Consent Statement: Not applicable.

Data Availability Statement: The raw data used to generate the graphs are available upon request.

Acknowledgments: We would like to express our gratitude to Zayed bin Sultan Center for Health Sciences, UAE University, for funding and supporting the project. We would like to thank Shaima Raji (Biology department, UAEU) and Neak Rafiq (Chemistry department, UAEU) for their suggestions and contributions.

Conflicts of Interest: The authors declare no conflict of interest.

\section{References}

1. Combs, G.F.; McClung, J.P. The Vitamins: Fundamental Aspects in Nutrition and Health, 5th ed.; Academic Press: Cambridge, MA, USA, 2016.

2. Windaus, A. The Chemistry of Irradiated Ergosterol. R. Soc. 1931, 108, 568-575.

3. Bikle, D.D. Vitamin D: An Ancient Hormone. Exp. Dermatol. 2010, 20, 7-13. [CrossRef]

4. Holick, M.F. Chapter 2-Photobiology of Vitamin D. In Vitamin D; Academic Press: Cambridge, MA, USA, 2011; pp. $13-22$.

5. Jones, G.; Prosser, D.E. The Activating Enzymes of Vitamin D Metabolism (25- and $1 \alpha$-Hydroxylases). In Vitamin D; Feldman, D., Pike, J.W., Adams, J.S., Eds.; Academic Press: Cambridge, MA, USA, 2011; pp. 23-41.

6. Zmijewski, M.A.; Carlberg, C. Vitamin D Receptor(s): In the Nucleus but Also at Membranes? Exp. Dermatol. 2020, 29, 876-884. [CrossRef]

7. Moore, D.D.; Kato, S.; Xie, W.E.N.; Mangelsdorf, D.J.; Schmidt, D.R.; Xiao, R.U.I.; Kliewer, S.A. International Union of Pharmacolog. LXII. The NR1H and NR1I Receptors: Constitutive Androstane Receptor, Pregnene X Receptor, Farnesoid X Receptor Alpha, Farnesoid X Receptor Beta, Liver X Receptor Alpha, Liver X Receptor Beta and Vitamin D Receptor. Am. Soc. Pharmacol. Exp. Ther. 2006, 58, 742-759.

8. Haussler, M.R.; Jurutka, P.W.; Mizwicki, M.; Norman, A.W. Vitamin D Receptor (VDR)-Mediated Actions of 1a,25(OH)2vitamin D3: Genomic and Non-Genomic Mechanisms. Best Pract. Res. Clin. Endocrinol. Metab. 2011, 25, 543-559. [CrossRef]

9. Choi, M.; Yamamoto, K.; Masuno, H.; Nakashima, K.; Yamada, S. Ligand Recognition by the Vitamin D Receptor. Bioorg. Med. Chem. 2001, 9, 1721-1730. [CrossRef]

10. Hoenderop, J.G.J.; Vennekens, R.; Müller, D.; Prenen, J.; Droogmans, G.; Bindels, R.J.M.; Nilius, B. Function and Expression of the Epithelial $\mathrm{Ca}^{2+}$ Channel Family: Comparison of Mammalian ECaC1 and 2. J. Physiol. 2001, 537, 747-761. [CrossRef] 
11. Chow, J.; Norng, M.; Zhang, J.; Chai, J. TRPV6 Mediates Capsaicin-Induced Apoptosis in Gastric Cancer Cells-Mechanisms behind a Possible New "Hot" Cancer Treatment. Biochim. Biophys. Acta Mol. Cell Res. 2007, 1773, 565-576. [CrossRef]

12. Ikeda, K.; Lu, C.; Weir, E.C.; Mangin, M.; Broadus, A.E. Transcriptional Regulation of the Parathyroid Hormone-Related Peptide Gene by Glococorticoids and Vitamin D in Human C-Cell Line. J. Biol. Chem. 1989, 264, 15743-15746. [CrossRef]

13. Wysolmerski, J.J. Parathyroid Hormone-Related Protein: An Update. J. Clin. Endocrinol. Metab. 2012, 97, 2947-2956. [CrossRef]

14. Yasui, W.; Akama, Y.; Kuniyasu, H.; Yokozaki, H.; Semba, S.; Shimamoto, F.; Tahara, E. Expression of Cyclin-Dependent Kinase Inhibitor P21(WAF1/CIP1) in Non-Neoplastic Mucosa and Neoplasia of the Stomach: Relationship with P53 Status and Proliferative Activity. J. Pathol. 1996, 180, 122-128. [CrossRef]

15. Saramäki, A.; Banwell, C.M.; Campbell, M.J.; Carlberg, C. Regulation of the Human P21(Waf1/Cip1) Gene Promoter via Multiple Binding Sites for P53 and the Vitamin D3 Receptor. Nucleic Acids Res. 2006, 34, 543-554. [CrossRef] [PubMed]

16. Stumpf, W.E. Vitamin D and the Digestive System. Eur. J. Drug Pharm. 2008, 33, 85-100. [CrossRef]

17. Wang, Y.; Zhu, J.; Deluca, H.F. Where Is the Vitamin D Receptor? Arch. Biochem. Biophys. 2012, 523, 123-133. [CrossRef] [PubMed]

18. Matusiak, D.; Murillo, G.; Carroll, R.E.; Mehta, R.G.; Benya, R.V. Expression of Vitamin D Receptor and 25-Hydroxyvitamin D3-1 A -Hydroxylase in Normal and Malignant Human Colon. Cancer Epidemiol. Biomark. Prev. 2005, 14, 2370-2377. [CrossRef]

19. Trowbridge, R.; Mittal, S.K.; Sharma, P.; Hunter, W.J.; Agrawal, D.K. Vitamin D Receptor Expression in the Mucosal Tissue at the Gastroesophageal Junction. Exp. Mol. Pathol. 2012, 93, 246-249. [CrossRef]

20. Christakos, S.; Li, S.; Cruz, J.D.L.; Shroyer, N.F.; Criss, Z.K.; Verzi, M.P.; Fleet, J.C. Vitamin D and the Intestine: Review and Update. Physiol. Behav. 2016, 176, 139-148. [CrossRef] [PubMed]

21. Cantorna, M.T.; Rogers, C.J.; Arora, J. Aligning the Paradoxical Role of Vitamin D in Gastrointestinal Immunity. Trends Endocrinol. Metab. 2019, 30, 459-466. [CrossRef]

22. Wen, Y.; Da, M.; Zhang, Y.; Peng, L.; Yao, J.; Duan, Y. Alterations in Vitamin D Signaling Pathway in Gastric Cancer Progression: A Study of Vitamin D Receptor Expression in Human Normal, Premalignant, and Malignant Gastric Tissue. Int. J. Clin. Exp. Pathol. 2015, 8, 13176-13184. [PubMed]

23. Fletcher, J.; Cooper, S.C.; Ghosh, S.; Hewison, M. The Role of Vitamin D in Inflammatory Bowel Disease: Mechanism to Management. Nutrients 2019, 11, 1019. [CrossRef] [PubMed]

24. Zhou, J.; Ge, X.; Fan, X.; Wang, J.; Miao, L.; Hang, D. Associations of Vitamin D Status with Colorectal Cancer Risk and Survival. Int. J. Cancer 2021, 149, 606-614. [CrossRef]

25. Shafrir, A.; Shauly-Aharonov, M.; Katz, L.H.; Paltiel, O.; Pickman, Y.; Ackerman, Z. The Association between Serum Vitamin d Levels and Helicobacter Pylori Presence and Eradication. Nutrients 2021, 13, 1-12. [CrossRef] [PubMed]

26. Dare, W.N.; Oyinbo, C.A.; Izunya, A.M. Study of the Structure of the Gastric Mucosa in the Mouse (Cell Population). J. Life Sci. Biomed. 2012, 2, 182-186.

27. Mahadevan, V. Anatomy of the Stomach. Surgery 2014, 32, 571-574. [CrossRef]

28. Hoffmann, W. Regeneration of the Gastric Mucosa and Its Glands from Stem Cells. Curr. Med. Chem. 2008, 15, 3133-3144. [CrossRef] [PubMed]

29. Karam, S.M.; Leblond, C.P. Identifying and Counting Epithelial Cell Types in the "Corpus" of the Mouse Stomach. Anat. Rec. 1992, 232, 231-246. [CrossRef] [PubMed]

30. Arnold, R.; Hulst, M.V.; Neuhof, C.H.; Schwarting, H.; Becker, H.D. Antral Gastrin-Producing G-Cells and SomatostatinProducing D-Cells in Different States of Gastric Acid Secretion. Gut 1982, 23, 285-291. [CrossRef] [PubMed]

31. Lynch, J.P.; Metz, D.C. Gastric Epithelial Stem Cells. Gastroenterology 2011, 140, 412-424. [CrossRef]

32. Karam, S.M. Lineage Commitment and Maturation of Epithelial Cells in the Gut. Front. Biosci. 1999, 4, 286-298. [CrossRef]

33. Holick, M.F. Vitamin D Status: Measurement, Interpretation and Clinical Application. Ann. Epidemiol. 2009, 19, 73-78. [CrossRef]

34. Wakayo, T.; Whiting, S.J.; Belachew, T. Vitamin D Deficiency Is Associated with Overweight and/or Obesity among Schoolchildren in Central Ethiopia: A Cross-Sectional Study. Nutrients 2016, 8, 190-201. [CrossRef]

35. Waldum, H.L.; Sandvik, A.K.; Brenna, E.; Petersen, H. Gastrin-Histamine Sequence in the Regulation of Gastric Acid Secretion. Gut 1991, 32, 698-701. [CrossRef] [PubMed]

36. Ross, A.C.; Taylor, C.L.; Yaktine, A.L.; Del Valle, H.B. Dietary Reference Intakes for Calcium and Vitamin D; The National Academic Press: Washington, DC, USA, 2011.

37. Wang, X.; Wang, T.; White, J.H.; Studzinski, G.P. Induction of Kinase Suppressor of RAS-1 (KSR-1) Gene by 1, a 25Dihydroxyvitamin D 3 in Human Leukemia HL60 Cells through a Vitamin D Response Element in the 5'-Flanking Region. Oncogene 2006, 25, 7078-7085. [CrossRef] [PubMed]

38. Zeitz, U.; Weber, K.; Soegiarto, D.W.; Wolf, E.; Balling, R.; Reinhold, G.; Genetics, M. Impaired Insulin Secretory Capacity in Mice Lacking a Functional Vitamin D Receptor. FASEB J. 2003, 17, 509-511. [CrossRef]

39. Cheng, J.B.; Motola, D.L.; Mangelsdorf, D.J.; Russell, D.W. De-Orphanization of Cytochrome P450 2R1. J. Biol. Chem. 2015, 278, 38084-38093. [CrossRef]

40. Usui, E.; Noshiro, M.; Okuda, K. Molecular Cloning of CDNA for Vitamin D, 25hydroxylase Mitochondria. FEBS J. 1990, 262, 135-138. [CrossRef]

41. Sakaki, T.; Sawada, N.; Komai, K.; Shiozawa, S.; Yamada, S.; Yamamoto, K. Dual Metabolic Pathway of 25-Hydroxyvitamin D 3 Catalyzed by Human. Eur. J. Biochem. 2000, 267, 6158-6165. [CrossRef] 
42. Han, Y.-P.; Kong, M.; Zheng, S.; Ren, Y.; Zhu, L.; Shi, H.; Duan, Z. Vitamin D in Liver Diseases: From Mechanisms to Clinical Trials. J. Gastroenterol. Hepatol. 2013, 28, 49-55. [CrossRef]

43. Yao, X.; Forte, J.G. Cell Biology of Acid Secretion by the Parietal Cell. Annu. Rev. Physiol. 2003, 65, 103-131. [CrossRef]

44. Antico, A.; Tozzoli, R.; Giavarina, D.; Tonutti, E.; Bizzaro, N. Hypovitaminosis D as Predisposing Factor for Atrophic Type A Gastritis: A Case-Control Study and Review of the Literature on the Interaction of Vitamin D with the Immune System. Clin. Rev. Allergy Immunol. 2012, 42, 355-364. [CrossRef] [PubMed]

45. Rugge, M.; Correa, P.; Dixon, M. F.; Fiocca, R.; Hattori, T.; Lechago, J.; Leandro, G.; Price, A. B.; Sipponen, P.; Solcia, E. Gastric Mucosal Atrophy: Interobserver Consistency Using New Criteria for Classification and Grading. Aliment. Pharmacol. Ther. 2002, $16,1249-1259$.

46. Naveh-Many, T.; Rahamimov, R.; Livni, N.; Silver, J. Parathyroid Cell Proliferation in Normal and Chronic Renal Failure Rats. The Effects of Calcium, Phosphate, and Vitamin D. J. Clin. Investig. 1995, 96, 1786-1793. [CrossRef]

47. Kallay, E.; Pietschmann, P.; Toyokuni, S.; Bajna, E.; Hahn, P.; Mazzucco, K.; Bieglmayer, C.; Kato, S.; Cross, H.S. Characterization of a Vitamin D Receptor Knockout Mouse as a Model of Colorectal Hyperproliferation and DNA Damage. Carcinogenesis 2001, 22, 1429-1435. [CrossRef]

48. Ohning, G.V.; Wong, H.C.; Lloyd, K.C.; Walsh, J.H. Gastrin Mediates the Gastric Mucosal Proliferative Response to Feeding. Am. J. Physiol. 1996, 271, 470-476. [CrossRef]

49. Kinoshita, Y.; Ishihara, S. Mechanism of Gastric Mucosal Proliferation Induced by Gastrin. J. Gastroenterol. Hepatol. 2000, 15 , 7-11. [CrossRef] [PubMed]

50. Al Menhali, A.; Keeley, T.M.; Demitrack, E.S.; Samuelson, L.C. Gastrin Induces Parathyroid Hormone-like Hormone Expression in Gastric Parietal Cells. Am. J. Physiol. 2017, 312, 649-657. [CrossRef] [PubMed] 